\title{
ІМУННИЙ СТАТУС І ДИНАМІКА ПОКАЗНИКІВ СИНДРОМУ ЕНДОГЕННОЇ ІНТОКСИКАЦІЇ ПРИ ЕКСПЕРИМЕНТАЛЬНОМУ ГОСТРОМУ ПОШИРЕНОМУ ПЕРИТОНІТІ НА ТЛІ СТРЕПТОЗОТОЦИНІНДУКОВАНОГО ЦУКРОВОГО ДІАБЕТУ
}

Вступ. Вивчення патогенетичних особливостей гострого поширеного перитоніту на тлі гіперглікемії $є$ актуальним питанням, що зумовлено тяжкістю перебігу гострого запалення очеревини, його атиповою клінічною картиною та високими показниками летальності при цій поєднаній патолосії.

мета дослідження - вивчити імунний статус та оцінити динаміку показників синдрому ендогенної інтоксикації у щурів з експериментальним гострим поширеним перитонітом на тлі стрептозотоциніндукованого цукрового діабету.

Методи дослідження. Експериментальне дослідження проведено на 48 білих щурах-самцях. Основну групу тварин було поділено на 3 підгрупи, в яких досліджували імунну відповідь (імуноглобуліни (Ig) класів A, M, G; CD3+, CD4+, CD8+, CD16+) та показники синдрому ендогенної інтоксикації (фрракції молекул середньої маси при довжині хвилі 254 і 280 нм (MCM 254 ma MCM $\left._{280}\right)$, еритроцитарний індекс інтоксикації (EII)). Цукровий діабет моделювали шляхом одноразового інтраперитонеального введення щурам стрептозотоцину (60 мг/кг). На 14-ту добу розвитку чукрового діабету в черевну порожнину тварин вводили 0,5 мл 10 \% профрільтрованої калової суспензії та ініціювали гострий поширений перитоніт. Щурам контрольної групи підшкірно вводили 0,9\% $\mathrm{NaCl}$.

Результати й обговорення. Виявлено тенденцію до зниження рівня IgG ma IgA впродовж усіх термінів розвитку поєднаної патології. Спостерігали надлишкове накопичення у крові IgM ma IgA на 1-шу добу і збільшення вмісту IgM на 3-тю добу розвитку перитоніту порівняно з контрольною групою. Встановлено десріцит T-клітинної ланки імунітету, який проявлявся зниженням рівня CD3+, CD4+, CD8+, CD16+y всіх підгрупах. Упродовж експерименту прогресуюче наростання ендогенної інтоксикації супроводжувалося підвищенням концентрації MCM $_{254}$ та MCM $_{280}$ ŭ Ell.

Висновки. У тварин із гострим поширеним перитонітом на тлі стрептозотоциніндукованого иукрового діабету прогресують процеси ендогенної інтоксикації, що проявляється збільшенням у сироватці крові концентрації MCM $_{254}$ та MCM $_{280}$ і величини Ell в динаміці розвитку поєднаної патології. Низькі показники клітинної імунної відповіді на тлі високих значень пептидів із середньою молекулярною масою підтверджують тяжкість перебігу гострого запалення очеревини за умов гіперглікемії.

КЛЮЧОВІ СЛОВА: гострий поширений перитоніт; стрептозотоциніндукований цукровий діабет; імунний статус; синдром ендогенної інтоксикації.

ВСТУП. Незважаючи на очевидні успіхи мікробіологічної діагностики, використання різноманітних антибактеріальних препаратів нового покоління, летальність при гострому поширеному перитоніті (ГПП) на тлі цукрового діабету залишається високою і становить 15-58 \% [1-4]. Метаболічні та морфоорункціональні зміни, що розвиваються за умови супутньої гіперглікемії, зумовлюють прогресування синдрому ендогенної інтоксикації при гострому запаленні очеревини, вираження якої є предметом багатьох експериментальних і клінічних досліджень. Так, В.В.Бойко та співавт. [5] і Р. І. Верба та співавт. [6] (C) Б. М. Вервега, 2021 відмічають збільшення вмісту циркулюючих імунних комплексів при наростанні ендотоксикозу. Різке підвищення рівня індексу лейкоцитарної інтоксикації та молекул середньої маси (МСM), на думку Я. Ю. Войтів та співавт., свідчить про прорив “печінкового бар'єру" і розвиток системних порушень [7]. Подібне зростання рівня всіх інтегральних індексів ендогенної інтоксикації (лейкоцитарний індекс інтоксикації за Кальф-Каліфом, модифрікований лейкоцитарний індекс інтоксикації за Островським, реактивна відповідь нейтрофрілів за Хабіровим, індекс співвідношення нейтроорілів та лімороцитів) описує також Е. А. Матусевич [8]. Високі значення лей- 
коцитарного індексу інтоксикації виявлено у пацієнтів з абдомінальним сепсисом та супутнім цукровим діабетом [9].

Перебіг перитоніту залежить від стану імунної системи, адекватності імунної відповіді, яка $\epsilon$ важливим критерієм у прогресуванні запального процесу в очеревині на тлі супутнього цукрового діабету. Ряд досліджень було спрямовано на вивчення клітинної та гуморальної ланок імунітету при ГПП [10-13]. Проте зв'язок між станом імунної системи та вираженням ендогенної інтоксикації при цій поєднаній патології, що являє собою багатокомпонентний загальний імунодепресивний стан, залишається недостатньо висвітленим, що і стало тригером дослідження.

Мета дослідження - вивчити імунний статус та оцінити динаміку показників синдрому ендогенної інтоксикації у щурів з експериментальним гострим поширеним перитонітом на тлі стрептозотоциніндукованого цукрового діабету (СТД).

МЕТОДИ ДОСЛІДЖЕННЯ. Експериментальне дослідження проведено на 48 статевозрілих білих щурах-самцях, яких утримували в умовах природної зміни режиму освітлення, температури та вологості повітря за стандартами віварію. Дослідження виконано відповідно до положень Європейської конвенції про захист хребетних тварин, що використовуються для дослідних та інших наукових цілей (Страсбург, 1986), Директиви Ради Європи 86/609/EЕC (1986); Закону України № 3447-IV "Про захист тварин від жорстокого поводження", Загальних етичних принципів експериментів на тваринах, ухвалених на Першому національному конгресі України 3 біоетики (2001).

Тварин було поділено на 2 групи: основну та контрольну. Основну групу розділили на 3 підгрупи з метою проведення досліджень на 1-шу, 3-тю і 7-му доби розвитку ГПП на тлі СТД (ці терміни відповідають реактивній, токсемічній та термінальній стадіям перитоніту).

Інсулінозалежну фрорму цукрового діабету відтворювали шляхом одноразового внутрішньочеревного введення тваринам натщесерце стрептозотоцину (“Sigma”) в дозі 60 мг/кг, розчинивши його безпосередньо перед введенням у 0,5 мл цитратного бусрера ( $\mathrm{pH}=4,5)$, молярною концентрацією 0,1 моль/л [14]. Перед ін'єкцією тричі здійснювали обробку правої здухвинної ділянки $10 \%$ розчином бетадину. Голку вводили під кутом $45^{\circ}$ до поверхні передньої черевної стінки до відчуття ії̈ “провалювання". 3 метою запобігання транзиторній гіпоглікемії тварини отримували протягом перших 24 год моделювання СТД розчин глюкози. На 14-ту добу роз- витку СТД у черевну порожнину щурів вводили 10 \% профрільтровану калову суспензію (0,5 мл на 100 г маси тіла), яку готували, змішуючи ізотонічний розчин і вміст сліпої кишки 3 інтактних тварин [15].

Вміст імуноглобулінів (Ig) класів A, M, G у сироватці крові досліджували за допомогою методу радіальної імунодифрузії глобулінів (G. Mancini et al.). Клітинну ланку імунітету (CD3+, CD4+, CD8+, CD16+) аналізували імуносрлуоресцентним методом, який ґрунтується на взаємодії моноклональних антитіл, мічених фрлуоресцентною міткою, з поверхневими антигенами лімфоцитів. Синдром ендогенної інтоксикації оцінювали за вмістом у сироватці крові фрракцій МСМ при довжині хвилі 254 і 280 нм $\left(\mathrm{MCM}_{254}\right.$ та $\left.\mathrm{MCM}_{280}\right)$ [16] та еритроцитарним індексом інтоксикації (EII) [17].

Статистичну обробку цифрових даних здійснювали за допомогою програмного забезпечення Excel i STATISTICA з використанням параметричних та непараметричних методів оцінки отриманих даних. Для всіх показників розраховували значення середньої арифметичної вибірки (M), її дисперсії і помилки середньої (m). Достовірність різниці значень між незалежними кількісними величинами визначали: при нормальному розподілі-за t-критерієм Стьюдента, в інших випадках - за U-критерієм Манна - Уїтні (достовірними вважали відмінності при р<0,05).

РЕЗУЛЬТАТИ Й ОБГОВОРЕННЯ. ПрИ ДОСЛідженні імуноглобулінів у тварин основної групи встановлено, що на 1-шу добу знизився вміст $\lg \mathrm{g}((3,31 \pm 0,07)$ г/л) і підвищився рівень $\lg \mathrm{M}$ $((2,95 \pm 0,07)$ г/л) та $\lg A((1,87 \pm 0,08)$ г/л) порівняно 3 контрольною групою (табл. 1). На 3-тю добу вміст IgG зменшився на $11 \%$, IgM - на $4 \%$, а $\operatorname{lgA}$ - на 35 \% порівняно з показниками контрольної групи. На 7-му добу концентрація IgG становила $(2,61 \pm 0,06)$ г/л, що на $18 \%$ нижче від показника контрольної групи. Рівень IgA зменшився на $44 \%$, тоді як IgM - зріс на 16 \% відносно контрольного значення.

На 1-шу добу розвитку ГПП на тлі СТД рівень Т-лімфоцитів (CD3+-клітин) становив $1,41 \pm 0,20 \times 10^{9}$ в 1 л. Порівняно 3 контрольною групою спостерігали зниження рівня ефекторних Т-клітин запалення: 3 фенотипом CD4+ - на $72 \%$, CD8+ - на 57 \%, CD16+ - на $67 \%$.

На 3-тю добу вміст CD3+-клітин зменшився на 80 \% порівняно з контрольною групою. Зниження рівня CD3+-клітин до 1,02 $00,18 \times 10^{9}$ в 1 л спостерігали на 7-му добу експерименту. В цей період вміст CD3+-клітин у підгрупі тварин 3 поєднаною патологією був на 493 \% статистично значимо меншим порівняно з контролем. 
Таблиця 1 - Концентрація імуноглобулінів у сироватці крові щурів із гострим поширеним перитонітом на тлі стрептозотоциніндукованого цукрового діабету (M士m)

\begin{tabular}{|c|c|c|c|c|}
\hline \multirow{3}{*}{ Показник } & \multicolumn{4}{|c|}{ Г Група піддослідних тварин } \\
\hline & \multirow[b]{2}{*}{$\begin{array}{c}\text { контрольна } \\
(n=8)\end{array}$} & \multicolumn{3}{|c|}{ основна $(n=35)$} \\
\hline & & $\begin{array}{c}\text { 1-ша підгрупа } \\
\text { (1-ша доба) }\end{array}$ & $\begin{array}{c}\text { 2-га підгрупа } \\
\text { (3-тя доба) }\end{array}$ & $\begin{array}{c}\text { 3-тя підгрупа } \\
\text { (7-ма доба) }\end{array}$ \\
\hline $\lg \mathrm{g}$, г/л & $3,61 \pm 0,05$ & $3,31 \pm 0,07^{*}$ & $\begin{array}{c}3,23 \pm 0,10^{\star} \\
\mathrm{p}_{1}<0,05\end{array}$ & $\begin{array}{c}2,61 \pm 0,06^{\star} \\
\mathrm{p}_{1}<0,05 \\
\mathrm{p}_{2}<0,05\end{array}$ \\
\hline $\lg \mathrm{M}$, г/л & $2,73 \pm 0,08$ & $2,95 \pm 0,07^{*}$ & $\begin{array}{c}2,62 \pm 0,07^{*} \\
p_{1}<0,05\end{array}$ & $\begin{array}{c}3,18 \pm 0,01^{*} \\
\mathrm{p}_{1}<0,05 \\
\mathrm{p}_{2}<0,05\end{array}$ \\
\hline $\lg \mathrm{A}$, г/л & $1,73 \pm 0,02$ & $1,87 \pm 0,08^{*}$ & $\begin{array}{c}1,13 \pm 0,09^{\star} \\
p_{1}<0,05\end{array}$ & $\begin{array}{c}0,98 \pm 0,0{ }^{\star} \\
\mathrm{p}_{1}<0,05 \\
\mathrm{p}_{2}<0,05\end{array}$ \\
\hline
\end{tabular}

Примітки:

1. * - відмінності відносно контрольної групи статистично достовірні $(p<0,05)$.

2. $p_{1}$ - достовірність відмінностей стосовно 1-ї доби ГПП на тлі СТд; $p_{2}$ - достовірність відмінностей щодо 3-ї доби гПП на тлі СТД.

Рівень ефректорних CD4+-клітин знизився в 3,9 раза на 3-тю добу й у 4,5 раза на 7-му добу відповідно порівняно з контролем.

Спостерігали збільшення вмісту клітин пам'яті CD8+ на 5 \% на 3-тю добу порівняно 3 1-ю. Прослідковували тенденцію до незначного зростання рівня CD8+ на 7-му добу $\left(1,05 \pm 0,13 \times 10^{9}\right.$ в 1 л) порівняно з 3-ю, проте цей показник був у 2,1 раза нижчим, ніж значення в контрольній групі.

Динаміку рівня CD16+ наведено в таблиці 2. Характерне максимальне його зниження на 70 \% на 7-му добу порівняно з контролем.

На 1-шу добу ГПП на тлі СТД вміст у сироватці крові фрракції $\mathrm{MCM}_{280}$, порівняно з контрольною групою, зріс на $94 \%$, на 3-тю - на $97 \%$, що виявилося на 4 \% більшим порівняно 3 1-ю добою (табл. 3). Найвищий рівень $\mathrm{MCM}_{280}$ спостерігали на 7-му добу розвитку поєднаної патології, він становив $(0,67 \pm 0,04)$ ум. од., що на $3 \%$ перевищувало аналогічний показник для тварин контрольної групи на 3-тю добу за умов експерименту.

Вміст у сироватці крові фрракції MCM $_{254}$ на 1-шу добу розвитку гострого запалення очеревини на тлі СТД, порівняно з контрольною гру- пою, збільшився на $280 \%$, а на 3-тю і 7-му доби - на 340 \% відповідно. Максимальні значення MCM $_{254}$ відмічали на 3-тю і 7-му доби.

Рівень Ell на 1-шу добу зріс на $127 \%$ порівняно 3 показником контрольної групи (табл. 3). Суттєво вищим він був на 3-тю $((78,8 \pm 2,6) \%)$ і 7 -му $((80,1 \pm 3,4) \%)$ доби відповідно. Максимальну величину EII спостерігали на 7-му добу, вона була на 1,6 \% більшою від показника на 3-тю добу.

Під час аналізу динаміки показників гуморальної ланки імунітету в підгрупах тварин із ГПП на тлі СТД виявлено тенденцію до зниження рівня IgG та IgA впродовж усіх термінів розвитку поєднаної патології. Спостерігали надлишкове накопичення у крові IgM та IgA на 1-шу добу i збільшення вмісту IgM на 3-тю добу розвитку перитоніту порівняно 3 контрольною групою. Наведені дані показали, що на тлі вираженого десекту гуморальної відповіді мав місце десріцит Т-клітинної ланки імунітету, який проявлявся зменшенням вмісту CD3+, CD4+, CD8+, CD16+ у всіх підгрупах.

При дослідженні МСМ у тварин з експериментальним ГПП на тлі СТД виявлено підвищення концентрації $\mathrm{MCM}_{254}$ та $\mathrm{MCM}_{280}$ і лінійне

Таблиця 2 - Показники клітинної ланки імунітету в щурів із гострим поширеним перитонітом на тлі стрептозотоциніндукованого цукрового діабету $(\mathrm{M} \pm \mathrm{m})$

\begin{tabular}{||l|c|c|c|c||}
\hline \multicolumn{1}{|c|}{ Термін дослідження } & $\begin{array}{c}\text { CD3+, } \\
\times 10^{9} \text { в } 1 \text { л }\end{array}$ & $\begin{array}{c}\text { CD4+, } \\
\times 10^{9} \text { в } 1 \text { л }\end{array}$ & $\begin{array}{c}\text { CD8+, } \\
\times 10^{9} \text { в } 1 \text { л }\end{array}$ & $\begin{array}{c}\text { CD16+, } \\
\times 10^{9} \text { в } 1 \text { л }\end{array}$ \\
\hline Контрольна група & $5,82 \pm 0,22$ & $1,35 \pm 0,14$ & $2,23 \pm 0,19$ & $3,81 \pm 0,20$ \\
\hline 1-ша підгрупа (1-ша доба) & $1,41 \pm 0,20$ & $0,38 \pm 0,16$ & $0,97 \pm 0,18$ & $1,28 \pm 0,19$ \\
\hline 2-га підгрупа (3-тя доба) & $1,17 \pm 0,22^{*}$ & $0,34 \pm 0,15$ & $1,02 \pm 0,17$ & $1,20 \pm 0,23^{*}$ \\
\hline 3-тя підгрупа (7-ма доба) & $1,02 \pm 0,18^{\star / / *}$ & $0,30 \pm 0,21^{*}$ & $1,05 \pm 0,13^{*}$ & $1,16 \pm 0,26^{\star / / *}$ \\
\hline
\end{tabular}

Примітки:

1. * - достовірність відмінностей стосовно 1-ї доби ГПП на тлі СТД.

2. \# - достовірність відмінностей щодо 3-ї доби ГПП на тлі СТД. 
Таблиця 3 - Динаміка вмісту молекул середньої маси та ендогенного індексу інтоксикації у тварин із гострим поширеним перитонітом на тлі стрептозотоциніндукованого цукрового діабету $(\mathrm{M} \pm \mathrm{m})$

\begin{tabular}{|c|c|c|c|c|}
\hline \multirow{3}{*}{ Показник } & \multicolumn{4}{|c|}{ Група піддослідних тварин } \\
\hline & \multirow[b]{2}{*}{$\begin{array}{c}\text { контрольна } \\
(n=8)\end{array}$} & \multicolumn{3}{|c|}{ основна $(n=35)$} \\
\hline & & $\begin{array}{c}\text { 1-ша підгрупа } \\
\text { (1-ша доба) }\end{array}$ & $\begin{array}{c}\text { 2-га підгрупа } \\
\text { (3-тя доба) }\end{array}$ & $\begin{array}{c}\text { 3-тя підгрупа } \\
\text { (7-ма доба) }\end{array}$ \\
\hline $\mathrm{MCM}_{280}$, ум. од. & $0,33 \pm 0,01$ & $0,64 \pm 0,05^{\star}$ & $\begin{array}{c}0,65 \pm 0,01^{*} \\
\mathrm{p}_{1}<0,05\end{array}$ & $\begin{array}{c}0,67 \pm 0,04^{*} \\
\mathrm{p}_{1}<0,05 \\
\mathrm{p}_{2}<0,05\end{array}$ \\
\hline $\mathrm{MCM}_{254}$, ум. од. & $0,05 \pm 0,01$ & $0,19 \pm 0,02^{*}$ & $\begin{array}{c}0,22 \pm 0,01^{*} \\
\mathrm{p}_{1}<0,05\end{array}$ & $\begin{array}{c}0,22 \pm 0,02^{*} \\
p_{1}<0,05 \\
p_{2}<0,05\end{array}$ \\
\hline Ell, \% & $32,2 \pm 1,5$ & $73,2 \pm 1,7^{*}$ & $\begin{array}{c}78,8 \pm 2,6^{*} \\
\mathrm{p}_{1}<0,05\end{array}$ & $\begin{array}{c}80,1 \pm 3,4^{*} \\
\mathrm{p}_{1}<0,05 \\
\mathrm{p}_{2}<0,05\end{array}$ \\
\hline
\end{tabular}

Примітки:

1. * - відмінності відносно контрольної групи статистично достовірні $(p<0,05)$.

2. $\mathrm{p}_{1}$ - достовірність відмінностей стосовно 1-ї підгрупи тварин із ГПП на тлі СТД; р $_{2}$ - достовірність відмінностей щодо 2-ї підгрупи тварин із ГПП на тлі СТД.

зростання EII протягом усього моделювання поєднаної патології, що свідчило про виражене прогресування синдрому ендогенної інтоксикації.

ВИСНОВКИ. У тварин із гострим поширеним перитонітом на тлі стрептозотоциніндукованого цукрового діабету прогресують процеси ендо- генної інтоксикації, що проявляється зростанням у сироватці крові концентрації $\mathrm{MCM}_{254}$ та $\mathrm{MCM}_{280}$ і величини EII в динаміці розвитку поєднаної патології. Низькі показники клітинної імунної відповіді на тлі високих значень пептидів із середньою молекулярною масою підтверджують тяжкість перебігу гострого запалення очеревини за умов гіперглікемії.

\section{СПИСОК ЛІТЕРАТУРИ}

1. The high elevation of c-reactive protein levels at admission represents an early mortality predictor in patients with complicated intra-abdominal infections / E. Dimitrov, G. Minkov, E. Enchev [et al.] // Trakia Journal of Sciences. - 2020. - 18. - P. 103-109.

2. Шевчук А. Г. Хірургічна патологія і цукровий діабет / А. Г. Шевчук, В.І.Боцюрко // Галиц. лікар. вісн. - 2012. - 19, число 1. - С. 8-12.

3. Evaluation of antimicrobial therapy management of 120 consecutive patients with secondary peritonitis / A. Sotto, J. Y. Lefrant, P. Fabbro-Peray [et al.] // J. Antimicrob. Chemother. - 2002. - 50. - P. 569-576.

4. Dejeu D. Acute abdomen in diabetic patients analysis of complications and mortality / D. Dejeu, V. Dejeu, A. Babeș. // Rom. J. Diabetes Nutr. Metab. Dis. - 2014. - 21 (4). - P. 277-284.

5. Діагностичні маркери синдрому ендогенної інтоксикації при поширеному перитоніті / В.В.Бойко, О. М. Шевченко, В. М. Лихман [та ін.] // Харк. хірург. школа. - 2014. - № 2. - С. 92-95.

6. Верба Р. І. Синдром ендогенної інтоксикації в щурів із гострим поширеним перитонітом на тлі мерказоліліндукованого гіпотиреозу / Р. I. Верба, І. М. Кліщ // Мед. хімія. - 2017. - 19, № 2 (71). - С. 12-18.
7. Войтів Я. Ю. Зміни деяких показників ендогенної інтоксикації при різних ступенях порушень фрункції кишок при перитоніті / Я. Ю. Войтів, В.С.Улянівський, І. В. Молокус // Молодий вчений. - 2015. - № 1 (16). C. $146-148$.

8. Матусевич Е. А. Метаболическая коррекция Т-клеточного иммунитета и эндогенной интоксикации при распространенном гнойном перитоните /Е. А. Матусевич // Новости хирургии. - 2015. - 23, № 1. C. $77-84$.

9. Особенности течения гнойно-септических осложнений в абдоминальной хирургии у больных с сахарным диабетом типа 2 / М. А. Дробков, Н. В. Рогова, А. Н. Акинчиц, О. И. Бутранова // Вестн. Волгоград. гос. мед. ун-та. - 2015. - Вып. 3 (55). - С. 78-81.

10. Саволюк С. І. Динаміка імунного статусу хворих на гнійний перитоніт / С. І. Саволюк, М. А. Гудзь, А. А. Жмур // Галиц. лікар. вісн. - 2016. - 23, число 3 (3). - С. 31-34.

11. Чурпій І. К. Динаміка показників клітинної ланки імунітету у хворих, оперованих з приводу перитоніту / І. К. Чурпій, О. В. Пиптюк, С. Б. Телемуха // Клінічна анатомія та оперативна хірургія. $-2014 .-13$, № 1. - C. 58-60. 
12. Показатели клеточного и гуморального иммунитета больных перитонитом, вызванным заболеваниями и травмами верхних мочевыводящих путей / В. А. Мусаилов, О. Э. Луцевич, П. Е. Крайнюков [и др.] // Москов. хирург. журн. - 2018. - № 4 (62). C. $39-44$.

13. Status of cellular immunity in rats under conditions of acute widespread petitonitis in the setting of diabetes mellitus / I. Y. Dziubanovskyi, S. R. Pidruchna, N. A. Melnyk [et al.] // Biointerface Research in Applied Chemistry. 2020. - 10, Issue 2. - P. 5243-5246.

14. Ramos-Lobo A. M. Streptozotocin-induced diabetes disrupts the body temperature daily rhythm in rats / A. M. Ramos-Lobo, D. C. Buonfiglio, J. CipollaNeto // Diabetol. Metab. Syndr. - 2015. - 7. - P. 39 DOI: 10.1186/s13098-015-0035-2.

\section{REFERENCES}

1. Dimitrov, E., Minkov, G., Enchev, E., Nikolov, S. Petrov, A. \& Yovtchev Y. (2020). The high elevation of c-reactive protein levels at admission represents an early mortality predictor in patients with complicated intraabdominal infections. Trakia Journal of Sciences, 18, 103-109. DOI:10.15547/tjs.2020.s.01.018

2. Shevchuk, A.H., \& Botsiurko, V.I. (2012). Khirurhichna patolohiia i tsukrovyi diabet [Surgical pathology and diabetes mellitus]. Halytskyi likarskyi visnyk-Galician Doctor's Bulletin, 19, 8-12 [in Ukrainian].

3. Sotto, A., Lefrant, J. Y., Fabbro-Peray, P., Tafuri, J., Navarro, F., Prudhomme, M., \& De La Coussaye, J. (2002). Evaluation of antimicrobial therapy management of 120 consecutive patients with secondary peritonitis. $J$ Antimicrob. Chemother., 50, 569-576. DOI: 10.1093/jac/ dkf167

4. Dejeu, D., Dejeu, V., \& Babeș, A. (2014). Acute abdomen in diabetic patients - analysis of complications and mortality. Rom. J. Diabetes Nutr. Metab. Dis., 21 (4), 277-284. DOI: 10.2478/rjdnmd-2014-0034

5. Boiko, V.V., Shevchenko, O.M., Lykhman, V.M., Lohachev, V.K., Merkulov, A.O., Bahirov, N.V., \& Klymenko V.P. (2014). Diahnostychni markery syndromu endohennoi intoksykatsii pry poshyrenomu perytoniti [Diagnostic markers of endogenous intoxication with diffuse peritonitis]. Kharkivska khirurhichna shkola Kharkiv Surgical School, 2, 92-95 [in Ukrainian].

6. Verba, R.I. \& Klisch, I.M. (2017). Syndrom endohennoi intoksykatsii v shchuriv iz hostrym poshyrenym perytonitom na tli merkazolilindukovanoho hipotyreozu [Syndrome of endogenous intoxication in rats with acute general peritonitis on the background of mercazoliluminduced hypothyroidism]. Medychna ta klinichna khimiia Medical and Clinical Chemistry, 2 (19), 12-18 [in Ukrainian].

7. Voitiv, Ya.Yu., Ulianivskyi, V.S., \& Molokus I.V. (2015). Zminy deiakykh pokaznykiv endohennoi intoksykatsii pry riznykh stupeniakh porushen funktsii kyshok pry perytoniti [Changes of some parameters of endogenic intoxication at various stages of intestinal dysfunction during peritonitis]. "Molodyi vchenyi" - "Young Scientist", 1 (16), 146-148 [in Ukrainian].
15. Экспериментальная модель распространенного калового перитонита / В. А. Лазаренко, В. А. Липатов, Ю. Ю. Блинков, Д. В. Скориков // Курский науч.-практ. вестн. "Человек и его здоровье". - 2008. № 4. - С. 128-132.

16. Никольская В. А. Биохимический аспект рассмотрения роли молекул средней массы в организме / В. А. Никольская, Ю. Д. Данильченко, 3. Н. Меметова // Ученые записки Таврического нац. ун-та им. В. И. Вернадского. Серия "Биология, химия". - 2013. № 1 (65). - С. 139-145.

17. Тогайбаев А. А. Метод определения эндогенной интоксикации / А. А. Тогайбаев, А. В. Кургузкин, И. В. Рикун // Лаб. дело. - 1988. - № 9. - С. 22-24.

8. Matusevich, E.A. (2015). Metabolicheskaya korrektsiya T-kletochnogo immuniteta i endogennoy intoksikatsii pri rasprostranennom gnoynom peretonite [Metabolic correction of $\mathrm{T}$ cell-mediated immunity and endogenous intoxication in generalized purulent peritonitis]. Novosti khirurgii - News of Surgery, 23 (1), 77-84 [in Russian].

9. Drobkov, M.A., Rogova, N.V., Akinchits, A.N., \& Butranova O.I. (2015). Osobennosti techeniya gnoynosepticheskikh oslozhneniy $v$ abdominalnoy khirurgii $u$ bolnykh s sakharnym diabetom tipa 2 [Specific characteristics of postoperative abdominal septic complications in patients with diabetes mellitus type 2]. Vestnik Volgogradskogo gosudarstvennogo meditsinskogo universiteta - Bulletin of Volgograd State Medical University, 3 (55), 78-81 [in Russian].

10. Savoliuk, S.I., Hudz, M.A., \& Zhmur A.A. (2016). Dynamika imunnoho statusu khvorykh na hniinyi perytonit [Changes of the immune status in patients with purulent peritonitis]. Halytskyi likarskyi visnyk - Galician Doctor's Bulletin, 23 (3), 31-34 [in Ukrainian]

11. Churpii, I.K., Pyptiuk, O.V., \& Telemukha, S.B. (2014). Dynamika pokaznykiv klitynnoi lanky imunitetu u khvorykh operovanykh z pryvodu perytonitu [Dynamics of cellular immunity patients operated on peritonitis]. Klinichna anatomiia ta operatyvna khirurhiia - Clinical Anatomy and Operative Surgery, 13 (1), 58-60 [in Ukrainian].

12. Musailov, V.A., Lutsevich, O.E., Kraynyukov, P.E., Esipov, A.V., \& Shishlo V.K. (2018). Pokazateli kletochnogo i gumoralnogo immuniteta bolnykh peritonitom, vyzvannym zabolevaniyami i travmami verkhnikh mochevyvodyashchikh putey [The cellular and humoral immunity in patients with peritonitis due to diseases and injuries of the upper urinary]. Moskovskiy khirurgicheskiy zhurnal Moscow Surgical Journal, 4 (62), 39-44. DOI: 10.17238/ issn2072-3180.2018.4.39-44 [in Russian].

13. Dziubanovskyi, I.Y., Pidruchna, S.R., Melnyk, N.A., Verveha, B.M., Hudyma, A.A., \& Logoyda, L.S. (2020). Status of cellular immunity in rats under conditions of acute widespread peritonitis in the setting of diabetes mellitus. Biointerface Research in Applied Chemistry, 10 (2), 5243-5246. DOI: 10.33263/BRIAC102.243246 
14. Ramos-Lobo, A.M., Buonfiglio, D.C., \& CipollaNeto, J. (2015). Streptozotocin-induced diabetes disrupts the body temperature daily rhythm in rats. Diabetology \& Metabolic Syndrome, 7, 39. DOI 10.1186/s13098-0150035-2

15. Lazarenko, V.A., Lipatov, V.A., Blinkov, Yu.Yu., \& Skorikov, D.V. (2008). [Experimental model of diffuse fecal peritonitis]. Kurskiy nauchno-prakticheskiy vestnik "Chelovek i ego zdorovye"-Kursk Scientific and Practical Bulletin "Man and his Health", 4, 128-132 [in Russian].

16. Nikolskaya, V.A., Danilchenko, Yu.D., \& Memetova, Z.N. (2013). Biokhimicheskiy aspekt rassmot- reniya roli molekul sredney massy $v$ organizme [Biochemical aspect of consideration of the role of average mass molecules in the body in the body]. Uchenyye zapiski Tavricheskogo natsionalnogo universiteta im. V.I. Vernadsk-ogo Ser.: Biologiya, khimiya - Scientific Notes of Taurida National University. VI Vernadsky Ser.: Biology, Chemistry, 1 (65), 139-145 [in Ukrainian].

17. Togaybayev, A.A., Kurguzkin, A.V., \& Rikun, I.V. (1988). Metod opredeleniya endogennoy intoksikatsii [Method for determining endogenous intoxication]. Lab. Delo - Lab. Business, 9, 22-24 [in Russian].

\section{ИМУННЫЙ СТАТУС И ДИНАМИКА ПОКАЗАТЕЛЕЙ СИНДРОМА ЭНДОГЕННОЙ ИНТОКСИКАЦИИ ПРИ ЭКСПЕРИМЕНТАЛЬНОМ ОСТРОМ РАСПРОСТРАНЕННОМ ПЕРИТОНИТЕ НА ФОНЕ СТРЕПТОЗОТОЦИНИНДУЦИРОВАННОГО САХАРНОГО ДИАБЕТА}

\section{Резюме}

Вступление. Изучение патогенетических особенностей острого распространенного перитонита на фроне гипергликемии является актуальным вопросом, что обусловлено тяжестью течения острого воспаления брюшины, его атипической клинической картиной и высокими показателями летальности при этой сочетанной патологии.

Цель исследования - изучить иммунный статус и оценить динамику показателей синдрома эндогенной интоксикации у крыс с экспериментальным острым распространенным перитонитом на фроне стрептозотоцининдуцированного сахарного диабета.

Методы исследования. Экспериментальное исследование проведено на 48 белых крысах-самцах. Основную группу животных было разделено на 3 подгруппы, в которых исследовали иммунный ответ (иммуноглобулины (Ig) классов A, M, G; CD3+, CD4+, CD8+, CD16+) и показатели синдрома эндогенной интоксикации (фрракции молекул средней массы при длине волны 254 и 280 нм (MCM ${ }_{254}$ и MCM $_{280}$ ), эритроцитарный индекс интоксикации (ЭИИ)). Сахарный диабет моделировали путем однократного интраперитонеального введения крысам стрептозотоцина (60 мг/кг). На 14-е сутки развития сахарного диабета в брюшную полость животных вводили 0,5 мл 10 \% профрильтрованной каловой суспензии и инициировали острый распространенный перитонит. Крысам контрольной группы подкожно вводили 0,9\% NaCl.

Результаты и обсуждение. Обнаружена тенденция к снижению уровня IgG и IgA в течение всех сроков развития сочетанной патологии. Наблюдали избыточное накопление в крови IgM и IgA на 1-е сутки и увеличение содержания IgM на 3-и сутки развития перитонита по сравнению с контрольной группой. Установлено дефицит Т-клеточного звена иммунитета, который проявлялся снижением уровня CD3+, CD4+, CD8+, CD16+ во всех подгруппах. В течение эксперимента прогрессирующее нарастание эндогенной интоксикации сопровождалось повышением концентрации MCM $_{254}$, MCM $_{280}$ и ЭИИ.

Выводы. У животных с острым распространенным перитонитом на фроне стрептозотоцининдуцированного сахарного диабета прогрессируют процессы эндогенной интоксикации, что проявляется увеличением концентрации $\mathrm{MCM}_{254}, \mathrm{MCM}_{280}$ и величины ЭИИ в динамике развития сочетанной патологии. Низкие показатели клеточного иммунного ответа на фоне высоких значений пептидов со средней молекулярной массой подтверждают тяжесть течения острого воспаления брюшины в условиях гипергликемии.

КЛЮЧЕВЫЕ СЛОВА: острыЙ распространенный перитонит; стрептозотоцининдуцированный сахарный диабет; иммунный статус; синдром эндогенной интоксикации. 


\section{IMMUNE STATUS AND DYNAMICS OF INDICATORS OF THE SYNDROME \\ OF ENDOGENOUS INTOXICATION IN EXPERIMENTAL ACUTE GENERALIZED PERITONITIS AGAINST THE BACKGROUND OF STREPTOSOTOCIN-INDUCED DIABETES MELLITUS}

\section{Summary}

Introduction. The study of pathogenetic features of acute generalized peritonitis against the background of hyperglycemia is an actual issue due to the severity of acute peritonitis, its atypical clinical picture and high mortality in this combined pathology.

The aim of the study - to investigate the immune status and assess the dynamics of endogenous intoxication syndrome in rats with experimental acute generalized peritonitis against the background of streptozotocin-induced diabetes mellitus.

Research Methods. The experimental study was performed on 48 adult white male rats. The main group of animals was divided into three subgroups, in which studied the immune response $(\lg \mathrm{G}, \lg \mathrm{M}, \lg A ; C D 3+, C D 4+$, $\mathrm{CD8}+, \mathrm{CD16+})$ and indicators of the endogenous intoxication syndrome $\left(\mathrm{MMM}_{254}\right.$ and $M \mathrm{MM}_{280}$, EII). Diabetes mellitus was simulated by a single intraperitoneal injection of streptozotocin (60 mg/kg). On day 14 of diabetes mellitus, rats were injected with $0.5 \mathrm{ml}$ of $10 \%$ filtered faecal suspension into the abdominal cavity and initiated acute generalized peritonitis. In the control group, rats were injected subcutaneously with $0.9 \% \mathrm{NaCl}$.

Results and Discussion. The tendency to decrease the levels of $\lg G$ and $\lg A$ during all terms of development of the combined pathology is revealed. Excessive accumulation of $\lg M$ and $\lg A$ in the blood on the first day and an increase of level of $\lg \mathrm{M}$ on the third day of peritonitis development were observed compared with the control group. Deficiency of T-cell immunity has been established, which is manifested by a decrease in the levels of CD3+, CD4+, CD8+, CD16+ in all subgroups. During the experiment, the progressive increase in endogenous intoxication was accompanied by an increase in level of $M M_{254}$ and $M M M_{280}$ and increase of erythrocyte intoxication index.

Conclusions. In animals with acute generalized peritonitis against the background of streptozotocin-induced diabetes processes of endogenous intoxication progress, which is manifested by an increase of $M_{M M} M_{254}$ and $M M M_{280}$ in the blood and the value of Ell in the dynamics of the combined pathology. Low rates of cellular immune response against the background of high values of peptides with average molecular weight confirm the severity of acute peritonitis under conditions of hyperglycemia.

KEY WORDS: acute generalized peritonitis; streptozotocin-induced diabetes mellitus; immune status; syndrome of endogenous intoxication. 